\title{
Reflections on the extinction of the National Council for Food and Nutrition Security and the confrontation of Covid-19 in Brazil
}

\section{Reflexões sobre a extinção do Conselho}

Nacional de Segurança Alimentar e

Nutricional e o enfrentamento

da Covid-19 no Brasil

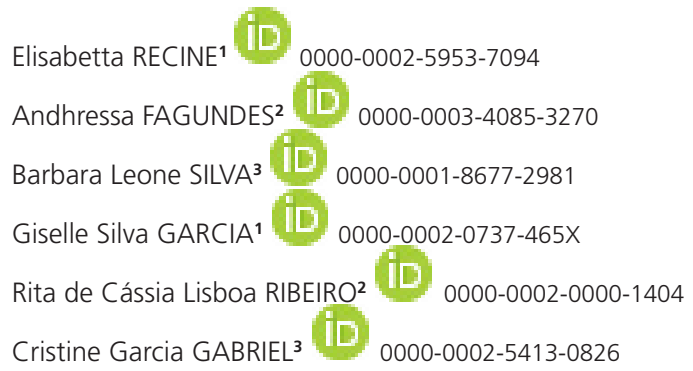

\section{A B S T R A C T}

The Provisional Measure 870/2019, which amended the Organic Law on Food and Nutrition Security and extinguished the Conselho Nacional de Segurança Alimentar e Nutricional (National Council for Food and Nutrition Security), has brought serious consequences to the Brazilian population, especially for the most vulnerable. This scientific note brings reflections on the trajectory of the Conselho Nacional de Segurança

\footnotetext{
1 Universidade de Brasília, Faculdade de Ciências da Saúde, Departamento de Nutrição, Programa de Pós-Graduação em Nutrição Humana. Campus Universitário Darcy Ribeiro, Asa Norte, 70910900, Brasília, DF, Brasil. Correspondence to: E. RECINE. E-mail: recine@unb.br

2 Universidade Federal de Sergipe, Departamento de Nutrição, Programa de Pós-Graduação em Ciências da Nutrição. São Cristóvão, SE, Brasil.

3 Universidade Federal de Santa Catarina, Centro de Ciências da Saúde, Programa de Pós-Graduação em Nutrição. Florianópolis, SC, Brasil.
}

How to cite this article

Recine E, Fagundes A, Silva BL, Garcia GS, Ribeiro RCL, Gabriel CG. Reflections on the extinction of the National Council for Food and Nutrition Security and the confrontation of Covid-19 in Brazil. Rev Nutr. 2020;33:e200176. https://doi. org/10.1590/1678-9865202033e200176 
Alimentar e Nutricional, the repercussions of its extinction in the last year, and the project to dismantle social protection policies in Brazil, with serious consequences at a time when the country is going through a crisis in public health due to the Covid-19 pandemic. The absence of the Conselho Nacional de Segurança Alimentar e Nutricional and the weakening of the set of policies for Food and Nutritional Security has mobilized the civil society to defend the human rights to food, food sovereignty, and to democracy itself. The resistance of the different social movements in order to maintain the spaces of civil participation related to Food and Nutrition Security public policies are still going to be long and arduous, demanding the continued vocalization and strengthening of partnership networks within the different movements of the organized civil society. Finally, we highlight the urgent need for restoration of the National System of Food and Nutritional Security (Sistema Nacional de Segurança Alimentar e Nutricional) with all its instances, and of other social policies, so that the negative consequences of the pandemic are avoided or mitigated and the State complies with its obligations to guarantee the rights of the Brazilian population.

Keywords: Coronavirus. Food and nutrition security. Human rights. Social control.

\section{RE S U M O}

A Medida Provisória no 870/2019, que alterou a Lei Orgânica de Segurança Alimentar e Nutricional e extinguiu o Conselho Nacional de Segurança Alimentar e Nutricional, tem trazido graves consequências à população brasileira, em especial, àqueles em situação de maior vulnerabilidade. Esta nota científica traz reflexões sobre a trajetória do Conselho Nacional de Segurança Alimentar e Nutricional, as repercussões de sua extinção no último ano e o projeto de desmonte das políticas de proteção social no Brasil, com graves desdobramentos no momento em que o país atravessa uma crise de saúde pública em decorrência da pandemia da Covid-19. A ausência do Conselho Nacional de Segurança Alimentar e Nutricional e a fragilização do conjunto de políticas de Segurança Alimentar e Nutricional tem mobilizado a sociedade civil para a defesa do direito humano à alimentação, da soberania alimentar e da própria democracia. A resistência dos diferentes movimentos sociais para manutenção dos espaços de participação da sociedade civil nas políticas públicas de Segurança Alimentar e Nutricional ainda será longa e árdua, demandando a continuidade da vocalização e fortalecimento de redes de parceria nos diferentes movimentos da sociedade civil organizada. Por fim, destaca-se que a recomposição do Sistema Nacional de Segurança Alimentar e Nutricional, com todas as suas instâncias, e das demais políticas sociais, constitui uma necessidade premente para que as consequências negativas da pandemia sejam evitadas ou atenuadas e o Estado cumpra com as suas obrigações para a garantia dos direitos da população brasileira.

Palavras-chave: Coronavirus. Segurança alimentar e nutricional. Direitos humanos. Controle social.

\section{INTRODUCTION}

Moments of crisis, especially acute ones, demonstrate a State's ability to fulfill its primary functions of protecting the population, ensuring adequate living conditions, and providing effective responses to common problems. This capacity results, among others things, from institutional, financial, and managerial aspects, but, mainly, from the choices made in relation to development paths, social justice, and realization of rights.

The Covid-19 pandemic, declared in March 2020 by the World Health Organization (WHO), has been putting this ability to proof and threatening the economy and health systems in countries around the world. Due to the rapid dissemination of the disease globally, the conflicts of information about the risks and protection factors, and the lack of effective treatment, social isolation has become the most recommended strategy to contain the spread of the virus. However, this measure was adopted unevenly among and within countries. Regardless, there was a strong retraction in the economic activity and an overload of the health systems [1,2].

In Brazil, the consequences of the Covid-19 pandemic dramatically illustrate the choices the country made throughout its history, including the most recent ones. Since the approval of the 
Constitutional Amendment (CA) 95 in 2016, which established a ceiling on public spending by the Federal Government, the weakening of the financing of health, education, and social protection systems were foreseen. Likewise, the approval of the labor and social security national reforms aggravated the situation of millions of precarious workers.

The Brazilian pre-pandemic scenario showed an accelerated increase in poverty and extreme poverty, as well as of the homeless population and the informality of work (which already struck $41.1 \%$ of the workforce in 2019), accompanied by setbacks in indicators that are sensitive to the worsening economic and social situation, such as child mortality, and income and race inequality $[3,4]$. With an increased unemployment rate of $12.9 \%$ in the first quarter of the pandemic - the lowest level of employees since the beginning of the Pesquisa Nacional por Amostra de Domicilio (PNAD, National Household Sample Survey) - , social isolation measures have had a strong impact on the work and income of the Brazilian population, which are deeply related with food and nutritional insecurity $[5,6]$.

The articulation of Segurança Alimentar e Nutricional (SAN, Food and Nutritional Security) actions in the country took place within the scope of the Sistema Nacional de Segurança Alimentar e Nutricional (SISAN, National Food and Nutritional Security System), which is integrated by a range of components with specific and distinct responsibilities, including actors from the government and the civil society. SISAN offered the possibility of improved inter-sector and inter-federative articulation to keep the priorities needed to guarantee SAN in the public agenda.

However, the announcement of the Provisional Measure (MP) 870/2019, on the first day of the Bolsonaro administration, brought about substantial changes that mischaracterized SISAN and accelerated its dismantling with drastic budget cuts and the weakening or extinction of institutions and reference teams of numerous policies and programs started in the previous years [7]. Converted into the Law 13.844/2019, the MP amended the Lei Orgânica de Segurança Alimentar e Nutricional (LOSAN, Organic Law on Food and Nutritional Security) and extinguished the Conselho Nacional de Segurança Alimentar e Nutricional (CONSEA, National Council for Food and Nutritional Security) [8]. That represented the suppression of the main instance of permanent popular participation in the SAN Policy, thus limiting the dialogue between civil society and government, the definition of agreed goals, and social control.

If the response to the existing challenges added to the health and social crises could be supported by the structure offered by SISAN, albeit with difficulty, the current disarticulation caused by the absence of the CONSEA in the essentially intersectoral SAN agenda results in the State's inaction in facing the crises. This, in turn, leads to a further expansion of inequalities, food insecurity, and to the violation of the human right to food. Emergency actions to guarantee SAN have been identified as urgent during the health crisis, demanding immediate state intervention in order to ensure income security, job protection, emergency food supply, and articulation of local governments in protecting the food system in the short, medium, and long terms [4,9].

\section{THE EXTINCTION OF THE CONSEA AND ITS DEVELOPMENTS}

The CONSEA, instituted in 1993 as a response to demands from the civil society and extinct the following year, was re-established in 2003, at the beginning of the Lula administration, as the space for social control of the SAN policies and programs. With the approval of LOSAN, in 2006, the Council joined SISAN and became responsible for convening the National SAN Conference, 
promoting dialogues between the government and the various representatives of the Brazilian civil society, and monitoring programs and actions [10]. Composed of 2/3 civil society representatives and $1 / 3$ government representatives, the Council directly assisted the Presidency by drawing up guidelines for the realization of the Direito Humano à Alimentação e Nutrição Adequadas (DHANA, Human Right to Adequate Food and Nutrition).

The Council's trajectory records important results, such as the successful campaign for the insertion of food as a fundamental right in the Federal Constitution, the regulation of the National SAN Policy (Decree 7.272/2010) that established the parameters for the preparation of the Plano Nacional de Segurança Alimentar e Nutricional (PLANSAN, National Plan of Food and Nutrition Security), the conception of the Law that improved the Programa Nacional de Alimentação Escolar (PNAE, National School Food Program) and ensured that 30\% of the Program's federal budget was destined for the purchase of food from family farming, the conception of the Programa de Aquisição de Alimentos (PAA, Food Acquisition Program), among others [10,11].

These results are internationally recognized, as recorded in The Global Nutrition Report of 2016, that points to the Council as one of the responsible for the good results Brazil showed in guaranteeing SAN, resulting from its articulations and dialogue with different sectors of the society and the government, which led Brazil to leave the United Nations (UN) Hunger Map $[12,13]$.

Therefore, the MP 870/2019 triggers the dismantling of a process of building a national policy-articulating system. Its serious consequences are harshly felt by the most vulnerable groups, especially during the current public health crisis, since the absence of this articulation between government and society magnifies the distancing of the public power from reality, its fragmentation, and the shrinkage of institutional and finalistic relations within the scope of SAN.

During the first half of 2019, state and municipal councils for SAN, national and international entities, and distinct groups and collectives of the civil society expressed their opposition to the MP 870. Several organizations came together in defense of the CONSEA and the DHANA in various manifestations like public hearings, motions, and the organization of "Banquetaços" - a public activity that resulted in the distribution of more than 20 thousand meals in more than 40 cities [4].

The civil society also articulated actions of advocacy related to the National Congress to mobilize deputies and senators to defend SISAN - interventions for the defense of rights and for the proposition of political changes in favor of marginalized groups, aiming to influence the public power's decision-making [14]. Besides that, countless meetings with different sectors were carried out, an international petition was launched for recording the support of organizations and people from other countries to the Council and the concerns about growing violations to the DHANA in Brazil. The National Public Defender's Office and the Federal Attorney for Citizens' Rights issued notes on the unconstitutionality of the action [15].

This articulation of resistance forms and actors materializes social participation as "the main element that supports the identity and the possibilities for maintaining SISAN" [16]. However, even as the fundamental role of independent social articulations is recognized, from an institutional point of view, the Councils are the formal space for the representation of the rights' holders in the formulation and monitoring of the SAN Policy. Thus, the Law 13.844/2019 imposes risks to the functioning and institutionality of the state and municipal SAN Councils. Although it does not directly affect these instances, there is a risk of a "cascading political effect in governments that do not feel comfortable with the proximity of the people", which tends to compromise the orientation of a fundamentally 
intersectoral and decentralized system that is dependent on the articulation between civil society and governments in the different administrative spheres [17].

While the pre-pandemic scenario already presented challenges for the performance of the local SAN Councils, including asymmetries of power, limitations in the promotion of diversity of representation and of coordination with municipalities, in addition to inadequate infrastructure conditions, it still stands out that, with the CONSEA's termination and the deactivation of the Câmara Intersetorial de Segurança Alimentar e Nutricional (CAISAN, Federal Intersectoral Chamber of Food and Nutrition Security), SAN policies are no longer monitored [16]. The National Plan of Food and Nutrition Security (PLANSAN) comes to an end without indications for new publications and without priorities defined for a new edition, which should have been defined by the VI National SAN Conference, that was supposed to take place in November 2019. Thus, it is pertinent to affirm that the extinction of the CONSEA is practically synonymous for the extinction of SISAN, hindering the principles of social participation and intersectorality that guided the policy system, and violating fundamental rights registered in the Federal Constitution [18].

\section{THE CHALLENGE OF FACING COVID-19 AFTER THE CONSEA EXTINCTION}

Strategies identified as fundamental to guarantee the DHANA in tackling the pandemic involve strengthening local economies, the capillarization of food supply, the protection of adequate and healthy food for vulnerable parts of the population, and the prioritization of systems of food that are healthy and sustainable [9]. In this respect, Brazil faces critical circumstances, since key strategies, such as the PAA, the Programa Bolsa Familia (PBF, Program Bolsa Familia), the PNAE, the Politica Nacional de Agroecologia e Produção Orgânica (PNAPO, National Policy on Agroecology and Organic Production), public financing for rural women and youth, among others, have recently suffered relevant attacks and have been the targets of budget cuts [7,19].

Thus, reflections on the impacts of the CONSEA's extinction are urgent. If its extinction occurs at a critical moment for the Brazilian population, such a problem is exacerbated by the current crisis that requires urgent measures of social protection, which include the guarantee of SAN and the monitoring of indicators sensitive to living conditions, such as child mortality, unemployment, and inequality of income, gender, and race [4].

Regarding the national SAN actions, we possibly regressed decades. With the exception of the PNAE - which remains in operation, despite the challenges for the proper attendance of students and for maintaining the link with family farming -, SAN actions currently have to deal with reduced or canceled budgets and weakened teams. This dismantling illustrates the fact that there has not been a single CAISAN meeting since January 2019, and that there is no space for dialogue and agreement on this topic with the federal government. If not having an articulate plan of actions to guarantee SAN would be a step backwards under normal circumstances, its inexistence during the Covid-19 crisis is no less than tragic.

Not only does the extinction of the CONSEA compromise the continuity of the SAN Policy and favors the dismantling of programs aimed at fully developing the DHANA, but also it dismantles the governance of states and municipalities in that sense, hurts and denies the principle of social participation as a central element of democracy, and ignores all the success of the Brazilian experiences in combating hunger and extreme poverty and promoting adequate and healthy nutrition. 
For having contributed to the inclusion of historically vulnerable segments of the population in the policy-formulation process, the CONSEA's priorities continue to be evoked and defended by the civil society in its movements, forums, articulations, and organizations, as well as by the local SAN councils. In the face of the current scenario of human rights violations and the pandemic, these organized groups called for the Popular Conference for Rights, Democracy, Sovereignty, and SAN, and defined a SAN agenda for coping with Covid-19 with a set of tenders, such as: the immediate revocation of the CA 95/2016, the creation of Emergency Committees to Combat Hunger, the guarantee of food and shelter for the homeless, the expansion of income and security transfers, the adequacy and maintenance of the public SAN equipment, the guarantee of food supply and policies for family farming, the resumption of the Cisterns Program, and the resumption and strengthening of protection policies geared towards traditional peoples, communities, and the black population [20].

\section{CONCLUSION}

In addition to exacerbating social inequalities, the context of the pandemic highlights the maintenance of SAN as a strategy to reduce inequalities and protect decent living conditions. Contrary to this conception, Brazil's political commitment and the effort made over the past decades to guarantee SAN are currently being unstructured.

Brazil has become the global epicenter of the pandemic and the prospect is that the country will suffer from serious economic and social consequences. This is not only due to the pandemic, but also justified in view of the recent years, and especially the current government, when social protection policies have been neglected, as well as the SAN agenda.

The civil society's tireless efforts compose an arduous and sensitive struggle against the political-institutional losses for the SAN policy resulting from the extinction of the CONSEA. Its extinction means the absence of a body that exerts pressure and requires compliance with the necessary measures for the protection of the DHANA. Despite, the strength of popular resistance has allowed some of the most urgent actions to enter the public agenda - such as the readjustment of the PNAE to the context of the pandemic, the defense of a budget restoration for the Food Acquisition Program, the local experiences of Emergency Committees for the Combat of Hunger, among others equally important.

This long and arduous path is nevertheless necessary, since the articulation of the civil society organized around the protection of the DHANA, defense of food sovereignty, democracy, and the right to participate in the country's political decisions are non-negotiable.

\section{CONTRIBUTORS}

All authors participated in the stages of conception and design of the article, analysis and interpretation of data, review and approval of the final version.

\section{RE FER E N C E S}

1. World Health Organization. Coronavirus disease (COVID-19) pandemic. Geneva: Organization; 2020 [cited 2020 May 25]. Available from: https://www.who.int/emergencies/diseases/novel-coronavirus-2019 
2. The Lancet. COVID-19: remaking the social contract. Lancet. 2020;1401. https://doi.org/10.1016/S0140-6 736(20)30983-1

3. Instituto Brasileiro de Geografia e Estatística. Desemprego cai para 11,8\% com informalidade atingindo maior nível da série histórica. Rio de Janeiro: Instituto; 2020 [cited 2020 Jul 28]. Available from: https://censo2020. ibge.gov.br/2012-agencia-de-noticias/noticias/25534-desemprego-cai-para-11-8-com-informalidadeatingindo-maior-nivel-da-serie-historica.html

4. Castro IRR. A extinção do conselho nacional de segurança alimentar e nutricional e a agenda de alimentação e nutrição. Cad Saúde Pública. 2019;35(2):1-4. https://doi.org/10.1590/0102-311X00009919\%0AA

5. Instituto Brasileiro de Geografia e Estatística. Pesquisa Nacional por Amostra de Domicílios Contínua: menu do produto taxa de desocupação das pessoas de 14 anos ou mais, mar-Rio de Janeiro: Instituto; 2020 [cited 2020 Jul 28]. Available from: https://www.ibge.gov.br/estatisticas/sociais/populacao/9171-pesquisanacional-por-amostra-de-domicilios-continua-mensal.html?=\&t=destaques

6. Jaime PC. The COVID-19 pandemic: implications for food and nutrition (in)security. Ciênc Saúde Coletiva. 2020;25(7):2505. Available from: https://doi.org/10.1590/1413-81232020257.12852020

7. Rede de Informação e Ação pelo Direito a se Alimentar (FIAN Brasil). Informe Direito Humano à Alimentação e Nutrição Adequadas 2019: Autoritarismo, negação de direitos e fome. Brasília; 2019 [cited 2020 May 25]. Avaliable from: https://fianbrasil.org.br/wp-content/uploads/2019/09/Resumo-Executivo-DHANA-PORTUG $\%$ C3\%8AS.pdf

8. Brasil. Lei no. 13.844, de 18 de junho de 2014. Estabelece a organização básica dos órgãos da Presidência da República e dos Ministérios; altera as Leis nos 13.334, de 13 de setembro de 2016, 9.069, de 29 de junho de 1995, 11.457, de 16 de março de 2007, 9.984, de 17 de julho de 2000, 9.433, de 8 de janeiro de 1997, 8.001 , de 13 de março de 1990, 11.952, de 25 de junho de 2009, 10.559, de 13 de novembro de 2002, 11.440, de 29 de dezembro de 2006, 9.613, de 3 de março de 1998, 11.473, de 10 de maio de 2007, e 13.346, de 10 de outubro de 2016; e revoga dispositivos das Leis nos 10.233, de 5 de junho de 2001, e 11.284, de 2 de março de 2006, e a Lei no 13.502, de $1^{\circ}$ de novembro de 2017. Diário Oficial da União, 18 jun 2019 [cited 2020 May 25]. Disponível em: http://www.planalto.gov.br/ccivil_03/_ato2019-2022/2019/ lei/L13844.htm

9. Valadares AA, Alves F, Galiza M, Silva SP. Agricultura familiar e abastecimento alimentar no contexto do Covid-19: uma abordagem das ações públicas emergenciais. Brasília: Instituto de Pesquisa Economica Aplicada; 2020.

10. Burlandy L. A construção da política de segurança alimentar e nutricional no Brasil: estratégias e desafios para a promoção da intersetorialidade no âmbito federal de governo. Ciênc Saúde Coletiva. 2009;14(3):851-60. https://doi.org/10.1590/S1413-81232009000300020

11. Vasconcelos FAG, Machado ML, Medeiros MAT, Neves JA, Recine E, Pasquim EM. Public policies of food and nutrition in Brazil: from Lula to Temer. Rev Nutr. 2019;32:1-13. https://doi.org/10.1590/1678-98 $65201932 \mathrm{e} 180161$

12. International Food Policy Research Institute. Global Nutrition Report - From promise to impact: ending malnutrition by 2030. International Food Policy Research Institute. Washington, DC; 2016 [cited 2020 May 25]. Avaliable from: https://www.ifpri.org/publication/global-nutrition-report-2016-promise-impact-endingmalnutrition-2030

13. Food And Agriculture Organization Of The United Nations, International Fund for Agricultural Development, World Food Programme. The State of Food Insecurity in the World 2014: strengthening the enabling environment for food security and nutrition. Roma; 2014 [cited 2020 May 25]. Avaliable from: http://www. fao.org/3/a-i4030e.pdf

14. Buffardi AL, Hearn S, Tilley H. Refining advocacy assessment: reflections from practice. Overseas Development Institute. London, UK; 2017;12.

15. Recine E, Garcia GS. A sociedade civil e a garantia da segurança alimentar e nutricional. In: Preiss PV, Schneider, S, Souza, GC. A Contribuição brasileira à segurança alimentar e nutricional sustentável. Porto Alegre: Editora da UFRGS; 2020.

16. Machado ML. A implementação do Sistema Nacional de Segurança Alimentar e Nutricional no contexto dos municípios brasileiros: uma pesquisa avaliativa com enfoque no ciclo das políticas públicas. Santa Catarina: Universidade Federal de Santa Catarina, 2020. Tese de Doutorado em Nutrição. 
17. Pierre J, Bonomo É. A extinção do consea nacional e seu impacto nos conselhos estaduais e municipais. São Paulo: Le Monde Diplomatique; 2020 [cited 2020 Jun 7]. Disponível em: https://diplomatique.org.br/aextincao-do-consea-nacional-e-seu-impacto-nos-conselhos-estaduais-e-municipais

18. MPF. Alimentação adequada: veto à lei que estabelece funcionamento do Consea viola a Constituição, aponta PFDC [Internet]. Ministério Público Federal. 2020 [cited 2020 May 25]. p. 2019-20. Available from: http://www.mpf.mp.br/pgr/noticias-pgr/alimentacao-adequada-veto-a-lei-que-estabelece-funcionamentodo-consea-viola-a-constituicao-aponta-pfdc

19. Sambuichi RHR, Almeida AFCS, Perin G, Spínola PAC, Pella AFC. O Programa de Aquisição de Alimentos (PAA): instrumento de dinamismo econômico, combate à pobreza e promoção da segurança alimentar e nutricional em tempos de Covid-19. Brasília, Instituto de Pesquisa Econômica Aplicada; 2020 [cited 2020 May 25]. Avaliable from: https://www.ipea.gov.br/portal/images/stories/PDFs/nota_tecnica/200518_nota_ tecnica_dirur_n_17.pdf

20. Conferência Nacional, Popular, Autônoma: por Direitos, Democracia e Soberania e Segurança Alimentar e Nutricional. Garantir o direito à alimentação e combater a fome em tempos de coronavírus: a vida e a dignidade humana em primeiro lugar! [Internet]. Brasília, DF: Fórum Brasileiro de Soberania e Segurança Alimentar e Nutricional (FBSSAN); 2020. p. 1-16. Available at: https://fbssan.org.br/wp-content/uploads/2020/04/2020recomendacoes-sobre-direito-alimentacao-no-contexto-da-covid-versao-2-de-abril-.pdf 